\section{Questión}

Periodismo / Comunicación ISSN 1669-6581

Continuamos las clases gracias a la Radio a pila

Rocío Gavrila - Paula Porta

Question/Cuestión, Vol. 2, №66, Agosto 2020

ISSN 1669-6581

https://perio.unlp.edu.ar/ojs/index.php/question/index

IICom-FPyCS-UNLP

\title{
CONTINUAMOS LAS CLASES GRACIAS A LA RADIO A PILA
}

\author{
WE CONTINUE CLASSES THANKS TO BATTERY RADIO
}

Rocio Gavrila

gavrilarocio@gmail.com

Profesora en Comunicación social

Referente de Educación Secundaria en ruralidad

Dirección Provincial de Educación Secundaria

Dirección General de Cultura y Educación

Provincia de Buenos Aires

\section{Entrevista sonora por Paula Inés Porta}

Doctora en Comunicación, Docente Investigadora Extensionista Directora de Question/CuestiónlICom (Instituto de Investigaciones en Comunicación) FPyCS UNLP https://orcid.org/0000-0002-1399- 


\section{Resumen}

Relato de la experiencia de escolaridad en la ruralidad en el contexto del aislamiento social preventivo y obligatorio.

Testimonios de Paula Sakalauskas, Directora de la Escuela Secundaria N`3 orientación en Comunicación, "Perla Fuente de Feola" y Gustavo Laup Director de la Escuela Secundaria №2 ambas de Nicanor Otamendi, Partido de General Alvarado. Provincia de Buenos Aires

Las Escuelas, están a un lado y otro de la vía producen programas para la Radio de la Escuela Secundaria N`2 y por este medio lograron mantener la continuidad pedagógica, además de las plataformas virtuales. Crearon el programa "Dos por tres nos encontramos", para ofrecer una vía más de comunicación, entrar a las casas y comunicarse con las familias. Cuentan además, con el apoyo de un exalumno como operador de la radio.

A través de la Radio, tienen llegada a todo el pueblo.

\section{Palabras clave}

Radio - Escolaridad - Ruralidad

\section{Abstract}

Account of the experience of schooling in rurality in the context of preventive and mandatory social isolation.

Testimonies of Paula Sakalauskas, Principal of The Secondary School No. 3 Orientation in Communication, "Perla Fuente de Feola" and Gustavo Laup Director of the Secondary School No.2 both of Nicanor Otamendi, Party of General Alvarado. Province of Buenos Aires 
The Schools, are on one side and another of the way produce programs for High School Radio No.2 and by this means managed to maintain pedagogical continuity, in addition to virtual platforms. They created the "Two by Three We Meet" program, to offer one more way of communication, enter the houses and communicate with the families. They also have the support of an alumni as a radio operator.

Through radio, they have arrived all over the village.

\section{Keywords}

Radio - Scholarship - Rurality

\section{Enlace 1}

Rocío Gavrila

https://go.ivoox.com/rf/55780203

\section{ENLACE 2}

Testimonios de Paula Sakalauskas, Directora de la Escuela Secundaria №3 orientación en Comunicación, "Perla Fuente de Feola" y Gustavo Laup Director de la Escuela Secundaria №2 ambas de Nicanor Otamendi, Partido de General Alvarado. Provincia de Buenos Aires

https://go.ivoox.com/rf/55781121 